\title{
Survival and growth of Pinus halepensis Miller seedlings in a semi-arid environment after forest soil transfer, terracing and organic amendments
}

\author{
A Roldán, I Querejeta, J Albaladejo, V Castillo \\ Centro de Edafología y Biología Aplicada del Segura-CSIC, Apdo 4195, 30080 Murcia, Spain
}

(Received 27 April 1995; accepted 3 January 1996)

\begin{abstract}
Summary - A field assay was carried out to evaluate the effectiveness of several methods for the afforestation of a semi-arid area of southeast Spain with Pinus halepensis. The trial was designed as a two factor factorial with four soil preparation treatments as the first factor (mechanical terracing, manual terracing, manual terracing with the addition of urban solid refuse [USR] and mechanical terracing with USR) and the addition of fresh forest soil to the planting hole as the second factor. Twentyone months after planting, the methods involving the addition of USR significantly enhanced $P$ halepensis performance, mechanical terracing with USR being the most effective treatment in improving the survival and growth of the pines. The addition of forest soil significantly enhanced $P$ halepensis growth in all the soil preparation treatments except in the manual terracing with USR. $P$ halepensis growth was strongly correlated with soil moisture content $(r=0.83 ; P<0.01)$ which was greatest in the mechanical terracing with USR treatment. Soil fertility levels, which were improved by organic amendment, were significantly correlated with seedling growth, particularly the phosphorus rates $(r=0.75 ; P<0.05)$. The positive effect of added forest soil appears to be of a microbiological nature.
\end{abstract}

\section{afforestation / Pinus halepensis / terracing / organic amendment / soil transfer}

Résumé - Survie et amélioration de la croissance de plants de Pinus halepensis Miller dans un environnement semi-aride après apport de sol forestier, travail du sol et amendement organique. Nous avons mis en place un essai d'amélioration de la croissance de jeunes plantations de Pinus halepensis dans une zone semi-aride du sud-est de l'Espagne. Les traitements suivants ont été appliqués comme facteurs principaux : travail mécanique du sol en terrases, travail manuel du sol, travail du sol en terrasse avec apport d'un amendement organique constitué de résidus solides urbains, et travail manuel du sol avec apport d'un amendement organique. Un apport de sol forestier a été appliqué en deuxième facteur. Vingt et un mois après la plantation, le travail du sol avec amendement organique augmente significativement la croissance de $\mathrm{P}$ halepensis. Le traitement quicombine le travail mécanique du sol et un amendement organique a été le plus efficace sur la survie et l'amélioration de la croissance des pins. L'apport de sol forestier a un effet positif sur la croissance des pins sauf dans le traitement qui combine travail manuel du sol et amendement organique. La croissance de $\mathrm{P}$ halepensis est corrélée à la teneur en eau du sol $(\mathrm{r}=0,83 ; \mathrm{P} \quad 0,01)$ qui est la plus élevée dans le traitement qui combine travail mécanique du sol et amendement organique. La teneur en phosphore qui est améliorée par les amendements organiques est corrélée avec la croissance des plants $(r=0,75 ; \mathrm{P}=0,05)$. L'effet positif d'un apport du sol forestier paraît être de nature microbiologique.

reboisement / Pinus halepensis / travail du sol / apport organique / apport de sol fórestier 


\section{INTRODUCTION}

Southern Europe is seriously threatened by soil erosion and desertification and there is a general agreement that the restoration of the plant cover is a valid way of mitigating the soil degradation processes leading to this desertification. However, it is difficult to determine how best to encourage plant cover, especially when planting tree species in degraded areas, where soil productivity is very low and total annual precipitation is lower than $300 \mathrm{~mm}$. In such hostile conditions an improvement in soil fertility and water storage capacity may be necessary for success (Albaladejo and Diaz, 1990; Roldán and Albaladejo, 1994).

The present methods of soil preparation for afforestation in the semi-arid Mediterranean areas are based almost exclusively on mechanical treatments. These methods increase infiltration and waterholding capacity, reduce runoff and help root development (Gonzalez Alonso, 1989; Serrada, 1990). However, in the process of soil preparation the profile is disturbed, the most fertile epipedons are eliminated and there is a negative impact on landscape (Finkel, 1986; García Abril et al, 1989; García Salmerón, 1990).

Organic amendment is a proven method of improving the physical and biological properties of a soil and its fertility in semi-arid degraded areas (Diaz et al, 1994; Roldán and Albaladejo, 1994) although its use in afforestation has hardly been tested. Very little is known about the effect of a single addition of organic matter on the growth of introduced plants. Among these materials, urban solid refuse (USR) offers some advantages that range from low cost and widespread availability to the environmental benefits involved in its disposal (Stocking and Albaladejo, 1994).

Likewise, the transfer of forest soil to the planting hole is an economical and effective method of introducing or improving the availability of rhizosphere microflora which is beneficial for plant development (Amaranthus and Perry, 1987).

The objective of this experiment was to evaluate the effectiveness of different methods of soil preparation (mechanical treatments, organic amendment and transfer of forest soil) on the establishment of $P$ halepensis in a semi-arid environment.

\section{MATERIALS AND METHODS}

\section{Field site}

The experimental area was located in El Aguilucho (UTM: 30SXG5395, $180 \mathrm{~m}$ above sea level), in the northern foothills of the Carrascoy range in Murcia Province (southeast Spain). The climate is semi-arid Mediterranean, with extremely hot and dry summers. The average annual rainfall is $300 \mathrm{~mm}$, occurring mostly in autumn and spring. The mean annual temperature is $18^{\circ} \mathrm{C}$, and the potential evapotranspiration reaches 900-1 $000 \mathrm{~mm}$ year $^{-1}$. The predominant soils are Lithic Xerorthents and Lithic Haploxerolls (Soil Survey Staff, 1975) with a sandy loam texture.

The topography of the area is shaped by many deep and wide gullies running in a south-north direction. The vegetation consists mainly of slow-growing shrubs with some $P$ halepensis spots. The ground cover is sparse, and the predominant species are Rosmarinus officinalis $\mathrm{L}$, Anthyllis cytisoides $\mathrm{L}$, Thymus $\mathrm{sp}$, Helianthemum sp and Fumana sp.

\section{Materials}

The forest tree used in this experiment was $P$ halepensis Miller. Seeds were sown in $300 \mathrm{cc}$ bags in a soil/peat mixture of 3:1. The seedlings were grown in the EI Valle nursery (Murcia) for 1 year without any fertilization.

The urban refuse used in the experiments was a solid fresh material, neither composted nor ground but allowed to mature naturally for 15 days. The refuse came from the Murcia Municipal Treatment Plant; analytical characteristics of the USR determined by standard methods (Page et al, 1982) are shown in table I. 
Table I. Analytical characteristics of the urban solid refuse used in the experiment.

\begin{tabular}{lc}
\hline Ash (\%) & 40.6 \\
pH (1:10 aqueous extract) & 6.8 \\
Conductivity (1:10; $\left.\mathrm{mS} \mathrm{cm}^{-1}\right)$ & 4.4 \\
Organic C (\%) & 25.3 \\
Total N (\%) & 1.19 \\
Total P (\%) & 0.55 \\
Extractable C (\%) & 4.81 \\
C fulvic acids (\%) & 3.17 \\
C humic acids (\%) & 1.64 \\
Carbohydrates (\%) & 4.95
\end{tabular}

The forest soil was taken from an established $P$ halepensis spot located $300 \mathrm{~m}$ from the experimental plots. The transferred soil was collected $3 \mathrm{~h}$ before planting from the feeder-root zone (top $20 \mathrm{~cm}$ of mineral soil) of randomly selected pine trees.

\section{Experimental design}

The trial was designed as a two factor factorial experiment, with four soil preparation methods as the first factor and the addition of fresh forest soil to the planting hole as the second factor. The soil preparation treatments were i) mechanical terracing (conventional method, treatment 1); ii) manual terracing (treatment 2); iii) manual terracing with the addition of USR (treatment 3 ); and iv) mechanical terracing with the addition of USR (treatment 4). Four experimental plots, $600 \mathrm{~m}^{2}$ each, were established on an homogeneous east-facing hillslope with a slope of $25 \%$.

Mechanical terraces (four terraces per plot, $4 \mathrm{~m}$ wide, $30 \mathrm{~m}$ long) were excavated in treatments 1 and 4 by a bulldozer during June 1992 . The subsoil lime crust present in these terraces was broken by deep ploughing along the planting line. Manual terraces (eight terraces in both treatments 2 and $3,0.8 \mathrm{~m}$ wide, $30 \mathrm{~m}$ long) were dug using shovels in October 1992; strips of natural vegetation were left between adjacent terraces. Urban refuse was applied to treatments 3 and 4 in a single application at the beginning of the experiment in October 1992. The dose used was $10 \mathrm{~kg} \mathrm{~m}^{-2}$ in both mechanical and manual terraces.
In the mechanical terraces, the organic amendment was incorporated into the top $30 \mathrm{~cm}$ of the whole terrace using a rotovator. In the manual terraces, the refuse was only incorporated into the planting holes using a shovel.

In November 1992, $80 P$ halepensis seedlings were planted in each plot. Planting holes $40 \mathrm{~cm}$ wide, $40 \mathrm{~cm}$ long and $40 \mathrm{~cm}$ deep were manually dug in the terraces. The seedlings were planted at least $1 \mathrm{~m}$ apart, one in each hole, in a single row per terrace. To introduce the second factor of the experiment (forest soil addition subtreatment), the plots were subdivided across the slope using 20 seedlings as edges. In each plot, $150 \mathrm{~mL}$ of pine forest soil was added at planting time to each of the 30 seedlings on the right-hand side. In the experimental design each of the 30 seedlings per subtreatment was treated as a replicate. The experiment was conducted under strictly natural conditions without any watering or weeding.

\section{Measurements}

Basal diameters and heights of the seedlings were measured with calipers and rules at the time of the planting, and every 3 months thereafter.

Soil moisture in the different treatments was determined gravimetrically $\left(105^{\circ} \mathrm{C}, 24 \mathrm{~h}\right)$ every 15 days. Ten sampling positions per treatment were randomly selected. Root-zone $(10-20 \mathrm{~cm})$ samples of $50 \mathrm{~g}$ were obtained at each point with hand-driven probes. In December 1993, soil samples were taken from 20 randomly selected planting holes per treatment. Soil analyses were conducted to characterize the chemical properties of the soils. Total $\mathrm{N}$ and $\mathrm{C}$ were assessed by pretreatment with $\mathrm{HCl}$ to eliminate carbonates (Colombo and Baccanti, 1989), followed by combustion at $1020^{\circ} \mathrm{C}$ and determination in an automatic nitrogen and carbon analyser. Available $P$ was extracted with sodium bicarbonate (Olsen et al, 1954) and determined by colorimetry according to Murphy and Riley (1962). K extractable with ammonium acetate was determined by flame photometry (Schollemberger and Simon, 1954). Electrical conductivity was determined potentiometrically from the $1: 1$ saturation extract. The carbohydrate content values were obtained by the anthrone colorimetric method (Brink et al, 1960) after hydrolysis with concentrated sulphuric acid using glucose standards. 
Growth data of the seedlings were transformed logarithmically and analysed using a two-way analysis of variance test; significant differences among treatments were determined by the Newman-Keuls test.

\section{RESULTS}

\section{P halepensis growth}

The heights of the pines grown without added forest soil are shown in figure 1. From the first summer onwards (9 months after planting) mechanical terracing with USR (treatment 4) significantly enhanced growth $(P<0.05)$ compared with the other treatments and this difference tended to increase. After 21 months, the mean height in treatment 4 was $95-173 \%$ greater than that in the other treatments. Manual terracing with USR amendment (treatment 3) also had a positive effect on $P$ halepensis growth, particularly in the first stages after planting. The two soil preparation treatments without organic amendment showed significantly lower height values.

Tree diameters responded similarly (fig 2). Mechanical terracing with USR yielded the highest growth rate, followed by manual terracing with added USR. During the first year of the experiment, the smallest diameters were recorded in the mechanical

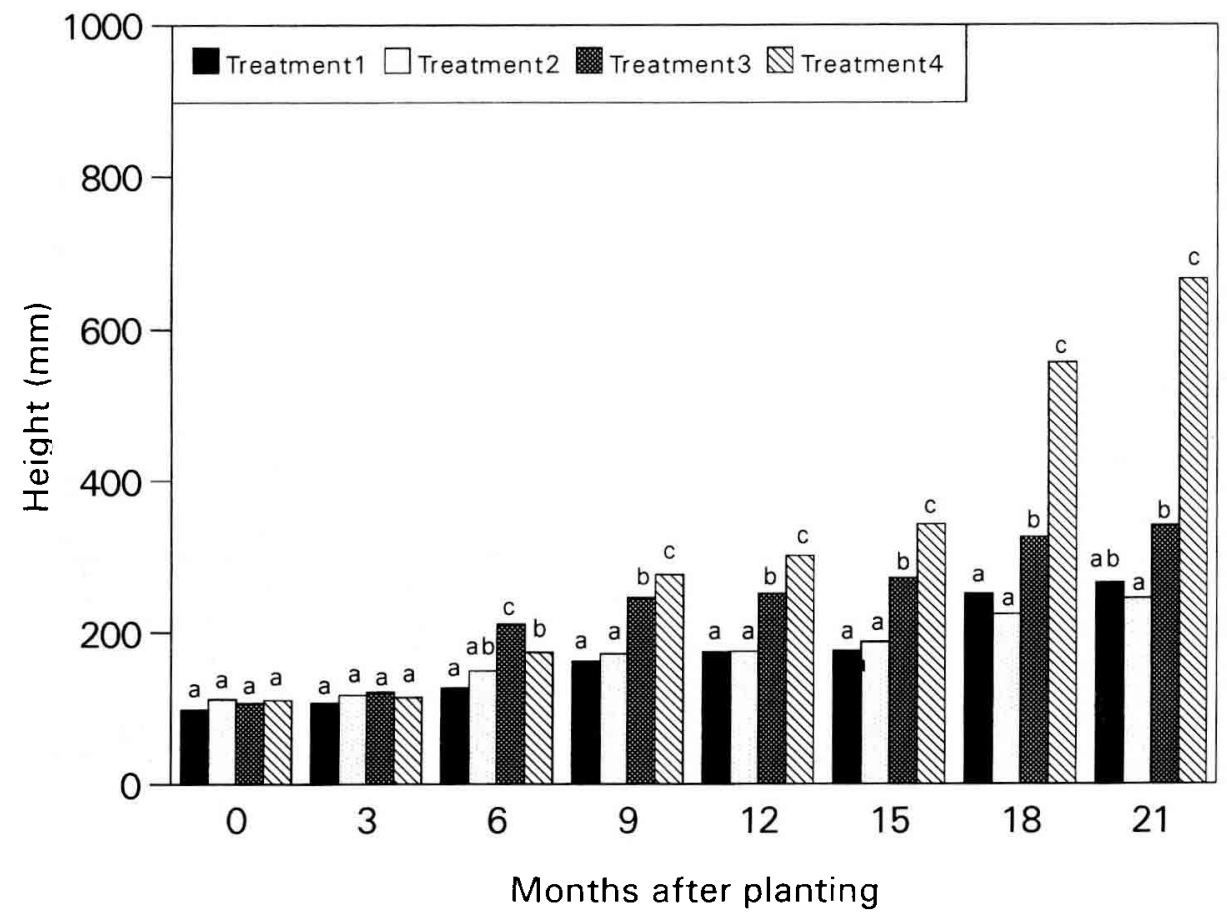

Fig 1. Height evolution of Pinus halepensis seedlings grown in various treated soils without added forest soil. Treatment 1: mechanical terracing; treatment 2: manual terracing; treatment 3: manual terracing + urban solid refuse (USR); treatment 4: mechanical terracing + USR. For each sampling date, bars sharing one letter do not differ significantly $(P<0.05)$ as determined by the Newman-Keuls test. Month $0=$ November 1992. 
Table II. Increases in basal diameter $(\mathrm{mm})$ of Pinus halepensis seedlings grown with forest soil addition to the plantation holes in regard to their controls in each soil preparation treatment.

\begin{tabular}{|c|c|c|c|c|c|c|c|c|}
\hline & \multicolumn{8}{|c|}{ Months after planting } \\
\hline & 0 & 3 & 6 & 9 & 12 & 15 & 18 & 21 \\
\hline Mechanical terracing & 0.167 & 0.089 & 0.145 & $0.840^{* *}$ & $0.903^{\star \star}$ & $1.170^{\star \star}$ & $1.620^{\star \star}$ & 1.347 \\
\hline Manual terracing & 0.004 & -0.100 & $0.479^{*}$ & 0.442 & 0.412 & 0.579 & 0.947 & $2.066^{x}$ \\
\hline Manual terracing & & & & & & & & \\
\hline + USR & -0.079 & 0.304 & -0.292 & -0.112 & -0.249 & -0.287 & -0.102 & -0.500 \\
\hline Mechanical terracing & & & & & & & & \\
\hline + USR & 0.060 & 0.158 & $0.950^{* *}$ & $1.177^{\star *}$ & $0.996^{\star *}$ & $1.120^{\star \star}$ & $1.495^{\star}$ & $1.451^{\star}$ \\
\hline
\end{tabular}

*," Significant at the 0.05 and 0.001 probability levels, respectively (Wilcoxon signed rank text).

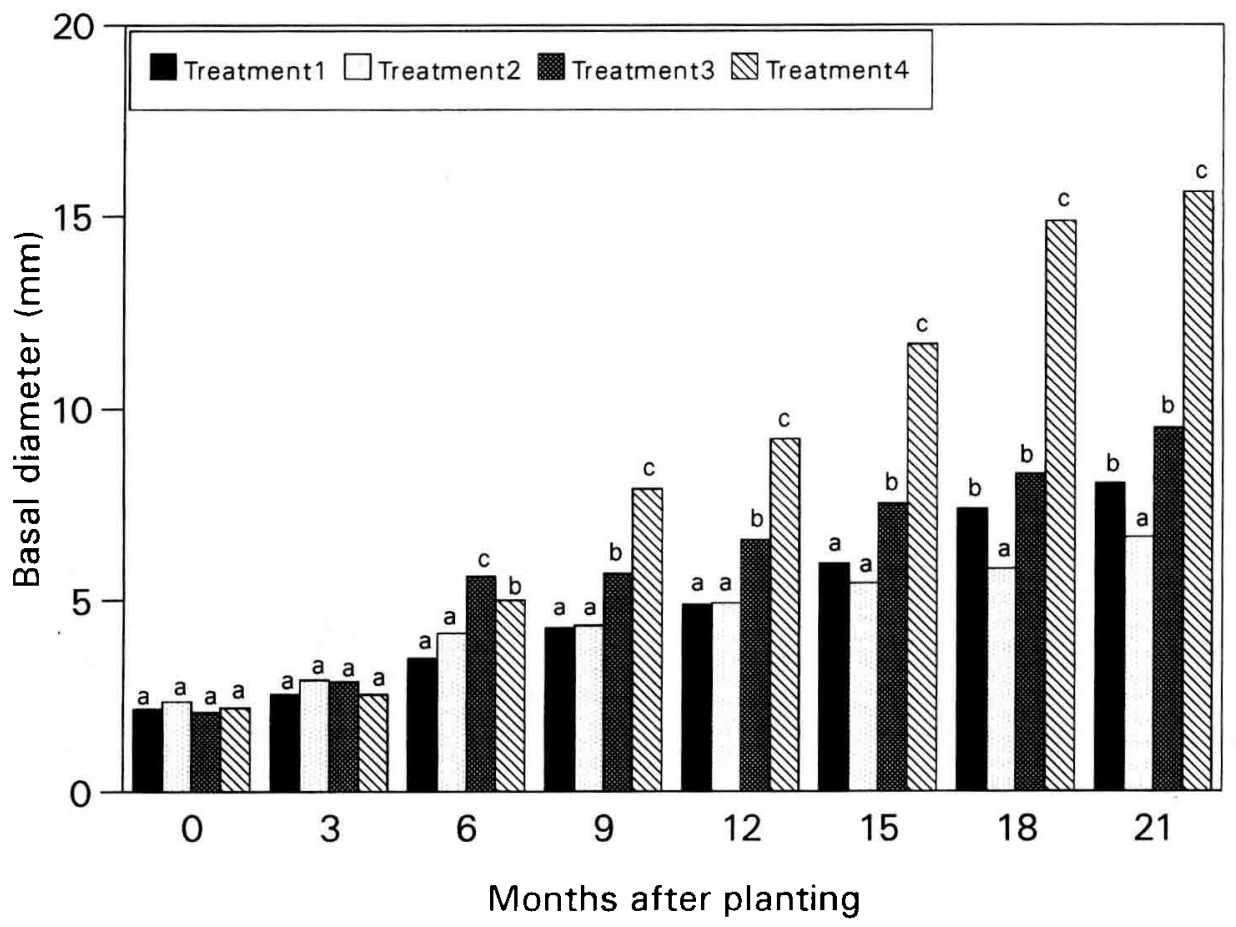

Fig 2. Basal diameter evolution of Pinus halepensis seedlings grown in various treated soils without added forest soil. Treatment 1: mechanical terracing; treatment 2: manual terracing; treatment 3 : manual terracing + urban solid refuse (USR); treatment 4: mechanical terracing + USR. For each sampling date, bars sharing one letter do not differ significantly $(P<0.05)$ as determined by the Newman-Keuls test. Month $0=$ November 1992. 
Table III. Increases in height ( $\mathrm{mm}$ ) of Pinus halepensis seedlings grown with forest soil addition to the plantation holes in regard to their controls in each soil treatment.

\begin{tabular}{|c|c|c|c|c|c|c|c|c|}
\hline & \multicolumn{8}{|c|}{ Months after planting } \\
\hline & 0 & 3 & 6 & 9 & 12 & 15 & 18 & 21 \\
\hline Mechanical terracing & 0.972 & 4.361 & 5.163 & $14.717^{\star}$ & 14.535 & 10.833 & 17.000 & $24.000^{*}$ \\
\hline Manual terracing & 3.708 & 7.833 & 17.000 & $32.792^{\star *}$ & $36.208^{\star *}$ & $21.579^{\star *}$ & $47.632^{*}$ & $67.604^{\star *}$ \\
\hline Manual terracing & & & & & & & & \\
\hline + USR & -6.083 & -3.583 & -2.369 & -16.864 & -0.252 & -10.598 & 5.972 & 33.712 \\
\hline Mechanical terracing & & & & & & & & \\
\hline+ USR & 4.822 & 8.889 & $29.878^{* *}$ & $82.226^{* t+}$ & $76.116^{\star \star \star *}$ & $78.513^{4 *}$ & $96.461^{\star \star \star *}$ & $98.853^{\star \star}$ \\
\hline
\end{tabular}

${ }^{\star},{ }^{\star \star},{ }^{\star \star \star}$ Significant at the $0.1,0.05$ and 0.001 probability levels, respectively (Wilcoxon signed rank text).

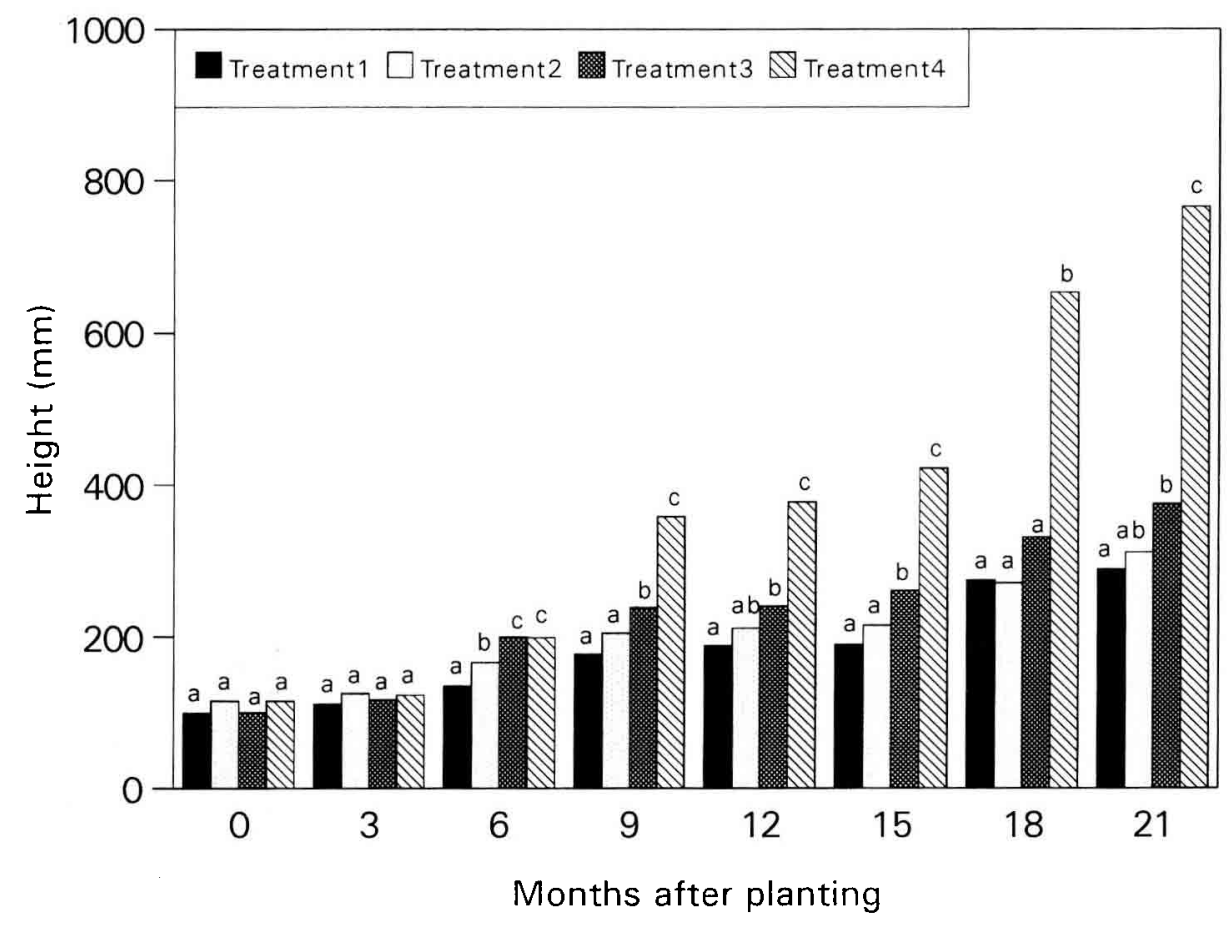

Fig 3. Height evolution of Pinus halepensis seedlings grown in various treated soils after added forest soil to the plantation holes. Treatment 1: mechanical terracing; treatment 2: manual terracing; treatment 3: manual terracing + urban solid refuse (USR); treatment 4: mechanical terracing + USR. For each sampling date, bars sharing one letter do not differ significantly $(P<0.05)$ as determined by the Newman-Keuls test. Month $0=$ November 1992. 


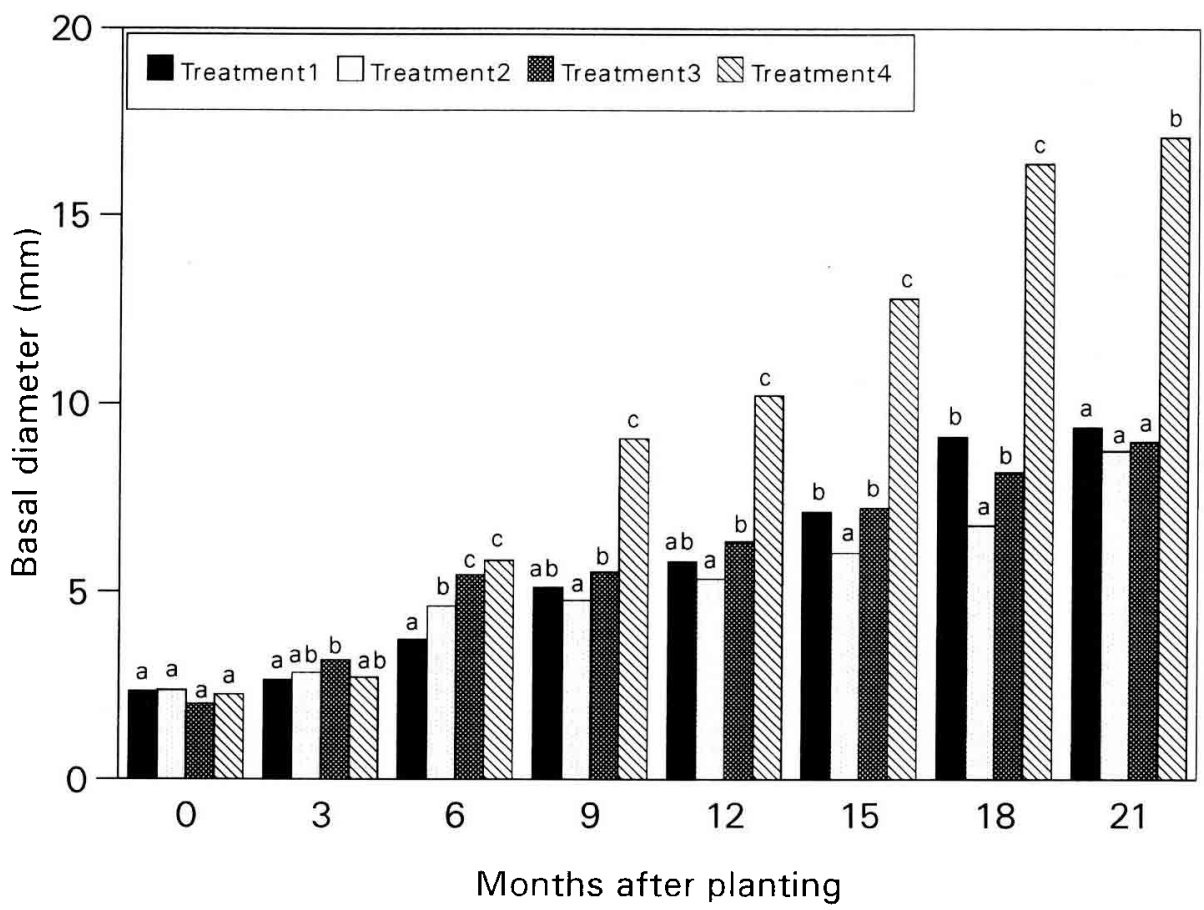

Fig 4. Basal diameter evolution of Pinus halepensis seedlings grown in various treated soils after added forest soil to the plantation holes. Treatment 1: mechanical terracing; treatment 2: manual terracing; treatment 3: manual terracing + urban solid refuse (USR); treatment 4: mechanical terracing + USR. For each sampling date, bars sharing one letter do not differ significantly $(P<0.05)$ as determined by the Newman-Keuls test. Month $0=$ November 1992.

terraces without USR, but after 18 months the seedlings in the manual terraces without refuse showed the lowest diameters.

The added forest soil also had a strong influence on the height of the pines (fig 3 ). Twenty-one months after planting, the seedlings grown in the mechanical terraces with USR were $100 \%$ taller than those in the other treatments. Manual terraces with USR also produced taller trees than those without added refuse. Regarding basal diameter growth (fig 4), the mechanical terraces with USR led to diameter values which were at least $85 \%$ higher than any of the other soil treatments 21 months after planting. Manual terraces without refuse showed the worst performance of all the treatments assessed.

The addition of forest soil to the planting holes enhanced pine growth in three of the four treatments (tables II and III) without any statistically significant interaction. A somewhat negative effect was observed in the manual terraces with USR amendment, although this was not statistically significant. In the rest of the soil preparation treatments, the addition of forest soil significantly enhanced both height and basal 
diameter of the seedlings. This positive effect was particularly noticeable in the mechanical terraces with USR.

\section{Survival rates}

Survival rates approximated $100 \%$ in all the treatments until spring 1994 (18 months after planting). Most of the deaths occurred during summer 1994 (figs 5 and 6). This important seasonal mortality almost exclusively affected the pines grown in the manual terraces and was reinforced by the addition of forest soil.

\section{Soil water content}

Figure 7 shows the effect of soil preparation on the soil water content. The total monthly rainfall recorded during the period of the experiment is shown in figure 8 . The results of the Wilcoxon signed rank test for comparing two series indicate that soil moisture contents in the mechanical terraces with USR amendment were significantly higher than in the other treatments. During the wet seasons, the soil moisture content was $28 \%$ higher than in the manual terraces with added USR, 23\% higher than in the mechanical terraces without USR and 52\% higher than in the manual terraces without refuse. These differences increased to 73 , 85 and $106 \%$, respectively, during the dry summers. In the manual terraces with USR, the soil moisture content was also significantly higher $(15 \%)$ than in the manual terraces without USR.

\section{DISCUSSION}

The experiment showed that the various soil preparation methods tested resulted in significant differences in the mortality and growth of $P$ halepensis in the semi-arid climate of southeast Spain. The addition of USR enhanced plant growth in all the treatments. Roldán and Albaladejo (1994) demonstrated that the application of small amounts of USR $\left(6 \mathrm{~kg} \mathrm{~m}^{-2}\right)$ also favoured pine growth under hydric stress conditions. Lambert et al (1985) also obtained positive results using sewage sludge in forest-tree seedling production.

It is proven that organic amendment improves the physical (Diaz et al, 1994; Roldán et al, 1994) and microbiological (Lynch and Bragg, 1983) characteristics of a soil, and its fertility (Borlisz and Malz, 1983; Albaladejo et al, 1994). It may also reduce

Table IV. Analytical characteristics of the soils in the different treatments.

\begin{tabular}{|c|c|c|c|c|}
\hline & Plot 1 & Plot 2 & Plot 3 & Plot 4 \\
\hline \multicolumn{5}{|l|}{ Available P } \\
\hline$\left(\mathrm{mg} \mathrm{g}^{-1}\right)$ & $0.015^{\mathrm{a}}$ & $0.017^{\mathrm{a}}$ & $0.042^{\mathrm{b}}$ & $0.111^{\mathrm{c}}$ \\
\hline Total N $(\%)$ & $0.050^{\mathrm{a}}$ & $0.077^{\mathrm{b}}$ & $0.127^{\mathrm{c}}$ & $0.146^{\mathrm{C}}$ \\
\hline \multicolumn{5}{|l|}{ Exchangeable $\mathrm{K}$} \\
\hline$\left(\mathrm{Cmol} \mathrm{kg}{ }^{-1}\right)$ & $0.173^{a}$ & $0.132^{\mathrm{a}}$ & $0.206^{\mathrm{ab}}$ & $0.683^{c}$ \\
\hline Organic $\mathrm{C}(\%)$ & $0.65^{\mathrm{a}}$ & $1.01^{b}$ & $1.10^{b}$ & $1.46^{\mathrm{C}}$ \\
\hline \multicolumn{5}{|l|}{ Electrical } \\
\hline conductivity (dS $\mathrm{m}^{-1}$ ) & $2.32^{\mathrm{a}}$ & $1.68^{\mathrm{a}}$ & $1.96^{\mathrm{a}}$ & $4.72^{b}$ \\
\hline \multicolumn{5}{|l|}{ Carbohydrates } \\
\hline (\% glucose) & $0.130^{a}$ & $0.255^{b}$ & $0.303^{b c}$ & $0.388^{c}$ \\
\hline
\end{tabular}

Data were collected 21 months after planting. Each value is a mean of 20 replicates. Plot 1: mechanical terracing plot 2: manual terracing; plot 3: manual terracing + USR; plot 4: mechanical terracing + USR. $^{\text {abc }}$ Values in rows sharing one letter do not differ significantly $(P<0.05)$ as determined by Duncan's test. 
plant diseases (Cook and Baker, 1983). In addition, increased plant growth is expected. On the other hand, some negative effects due to the toxicity of USR have been mentioned (Roldán and Albaladejo, 1993; Keeling et al, 1994). However, it is noteworthy that in a previous field assay (Roldán and Albaladejo, 1994) the USR quantities also applied in our experiment produced no inhibitory effect on $P$ halepensis growth.

The increased $N$ and $P$ contents of soils resulting from the incorporation of USR is particularly interesting when dealing with degraded forest soils, where these nutrients exist in concentrations limiting for tree development. The addition of USR yielded bigger fertility increases in the mechanical terraces than in the manual ter- races (table IV), which might be due to the different application techniques employed in the two treatments. In the manual terraces, the USR was added to the planting holes only, originating an edge effect that did not appear in the mechanical terraces. This may have determined different rates of organic matter mineralization as well as changes in microbial populations, resulting in dissimilar nitrogen biological fixation rates (Forster, 1980) and differing activities of the phosphate solubilizing microorganisms (Barea et al, 1975).

Differences in fertility may explain the observed improvement in $P$ halepensis growth with added USR, but they do not explain the better growth of the pines in the mechanical terraces compared to that in the manual terraces with USR. Although

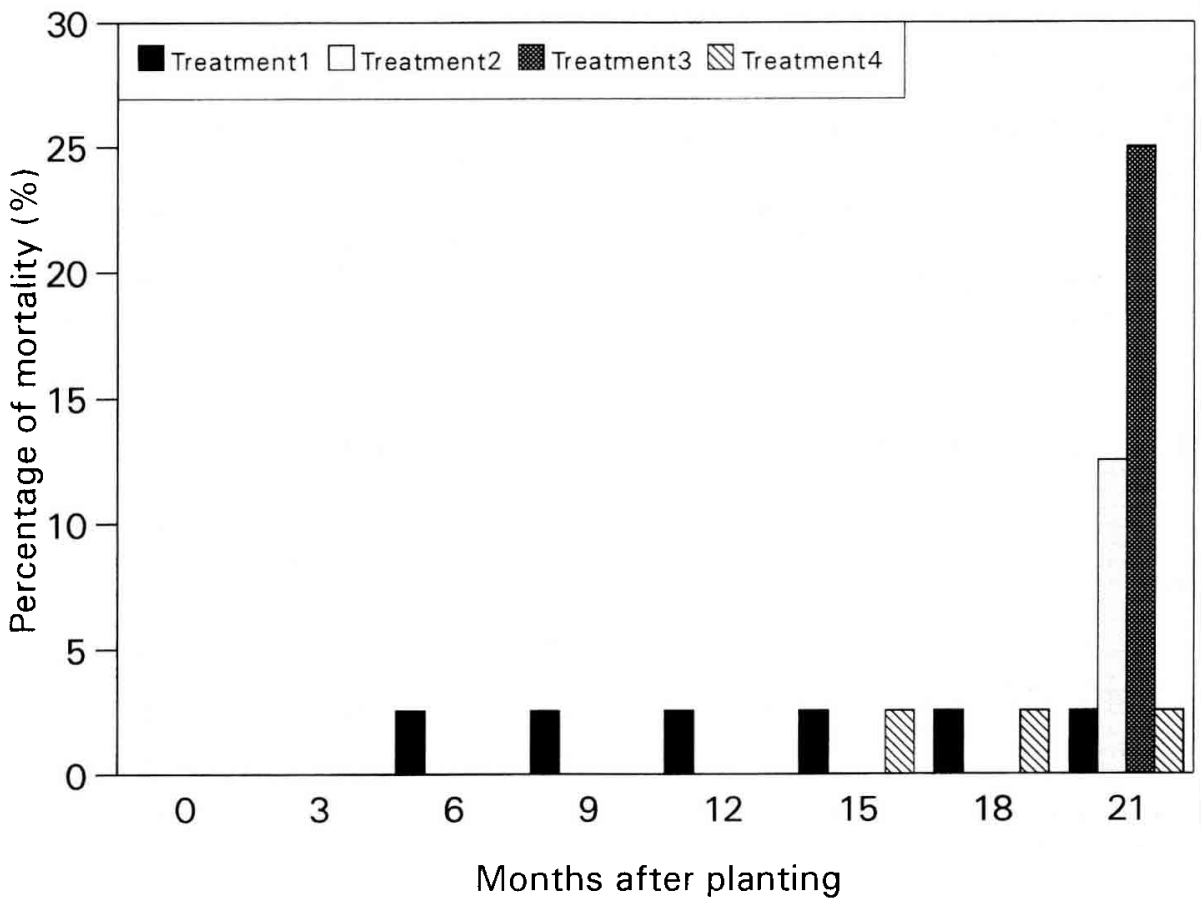

Fig 5. Mortality percentages of Pinus halepensis seedlings grown in various treated soils without added forest soil to the plantation holes. Treatment 1: mechanical terracing; treatment 2: manual terracing; treatment 3: manual terracing + urban solid refuse (USR); treatment 4: mechanical terracing 
nutrient concentrations were significantly higher in the former treatment, the levels of $N, P$ and $K$ in the manual terraces were by far superior to those considered limiting for coniferous growth (Marshner, 1986; Cumming, 1993; Roldán and Albaladejo, 1994).

Water availability is the main limiting factor for the establishment of a tree cover in semi-arid areas, where the average annual rainfall is around $300 \mathrm{~mm}$. Under these climatic conditions, the main objective of any soil preparation technique should be to increase the amount of water available for plant growth. One of the best known methods for improving physical properties of a soil is to add materials rich in easily decomposible carbon compounds. The application of these materials improves soil structure, since they stimulate aggregate formation and stabilization (Glaub and Gouleke, 1989; Diaz et al, 1994), diminish bulk density by increasing porosity (Biswas and Koshla, 1971; Hall and Coker, 1983), and favour infiltration processes and waterholding capacity (Gupta et al, 1977; Khaleel et al, 1981).

Mechanical terracing of slopes is a widely used technique in afforestation projects in Mediterranean Spain (García Salmerón, 1990). It helps to limit runoff and promotes infiltration (Dent and Murtland, 1990). In our experiment, the combination of mechanical terracing and USR addition led to an increase in soil water content compared to the other treatments. This increase was particularly significant during the driest periods, and consequently $P$ halepensis development was less limited by summer

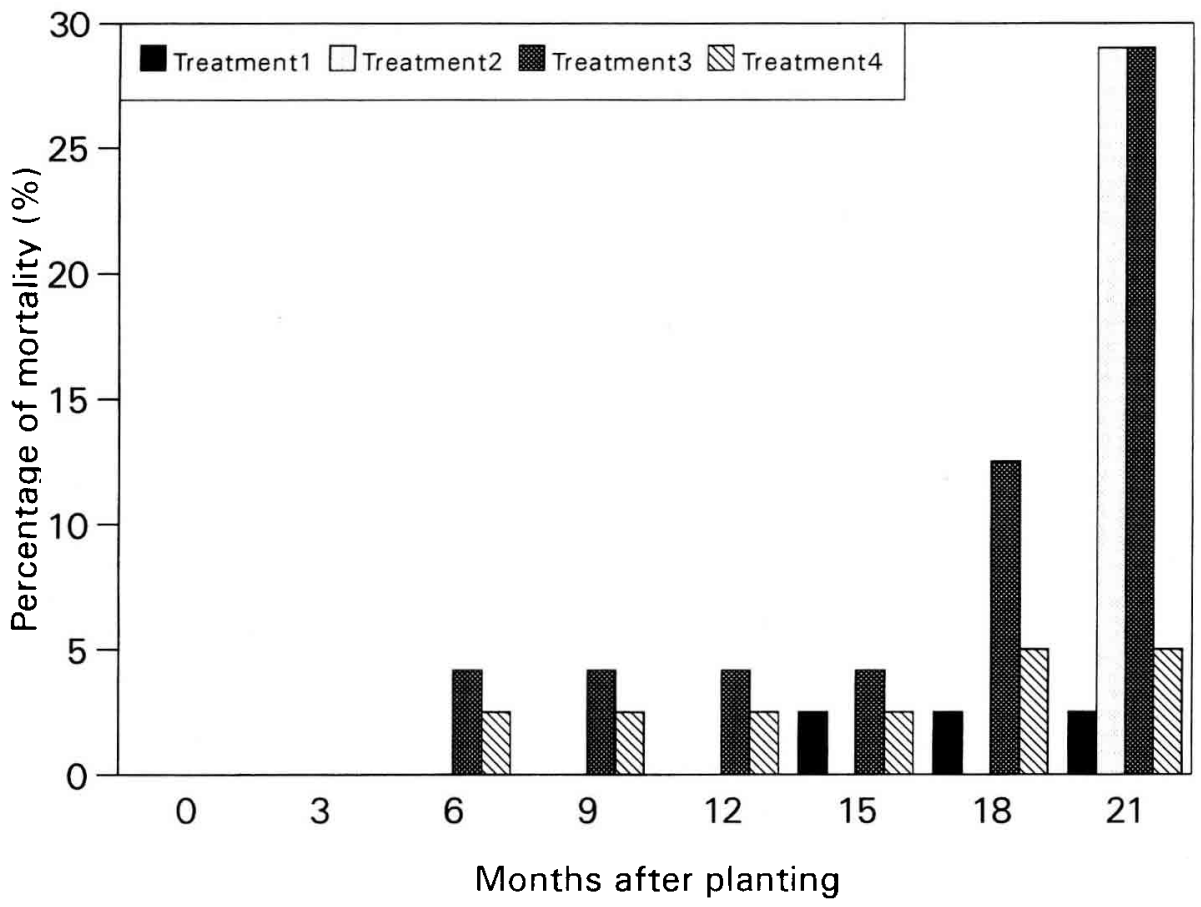

Fig 6. Mortality percentages of Pinus halepensis seedlings grown in various treated soils with added forest soil to the plantation holes. Treatment 1: mechanical terracing; treatment 2: manual terracing; treatment 3: manual terracing + urban solid refuse (USR); treatment 4: mechanical terracing + USR. 


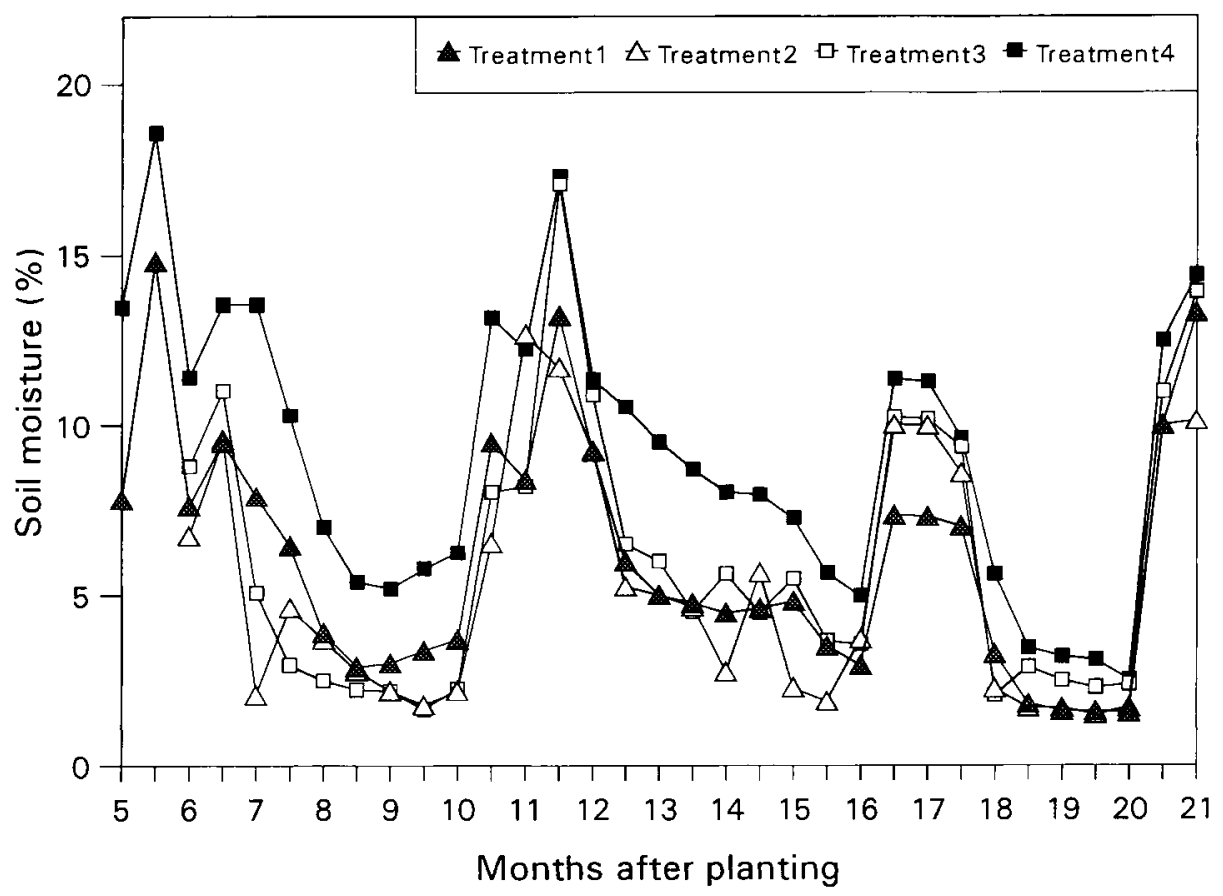

Fig 7. Evolution of the gravimetrical soil moisture contents in the experimental plots where Pinus halepensis seedlings were grown. Treatment 1: mechanical terracing; treatment 2: manual terracing; treatment 3: manual terracing + urban solid refuse (USR); treatment 4: mechanical terracing + USR. Month $5=$ April 1992. Each value is a mean of ten replicates.

droughts in this treatment. The increase in soil moisture caused by USR application to the manual terraces was lesser and no significant differences between dry and wet periods were observed. The addition of USR increased the water-holding capacity as well as fertility, and consequently these variables were highly correlated $(r=0.91$, $P<0.05)$. $P$ halepensis growth was well correlated with the soil moisture content $(r=0.83, P<0.01)$. The concentrations of $\mathrm{N}, \mathrm{P}$ and $\mathrm{K}$ were also correlated with pine growth, particularly the available phosphorus $(r=0.75, P<0.05)$. Multiple regression analysis showed that the combination of soil water content and $P$ concentration explained $92 \%$ of the variance observed in pine growth.

Mechanical terracing and the addition of USR synergetically favoured the development of $P$ halepensis. In spite of this, during the first months of the experiment no significant differences with the other treatments were observed and, 6 months after planting, the seedlings in the manual terraces with USR were larger. Mechanical terracing showed no positive effects during these first stages of the experiment, probably because the removal of the superficial horizons negatively affected the structure (Barber and Romero, 1994) and the microbiological activity of the soil, although 


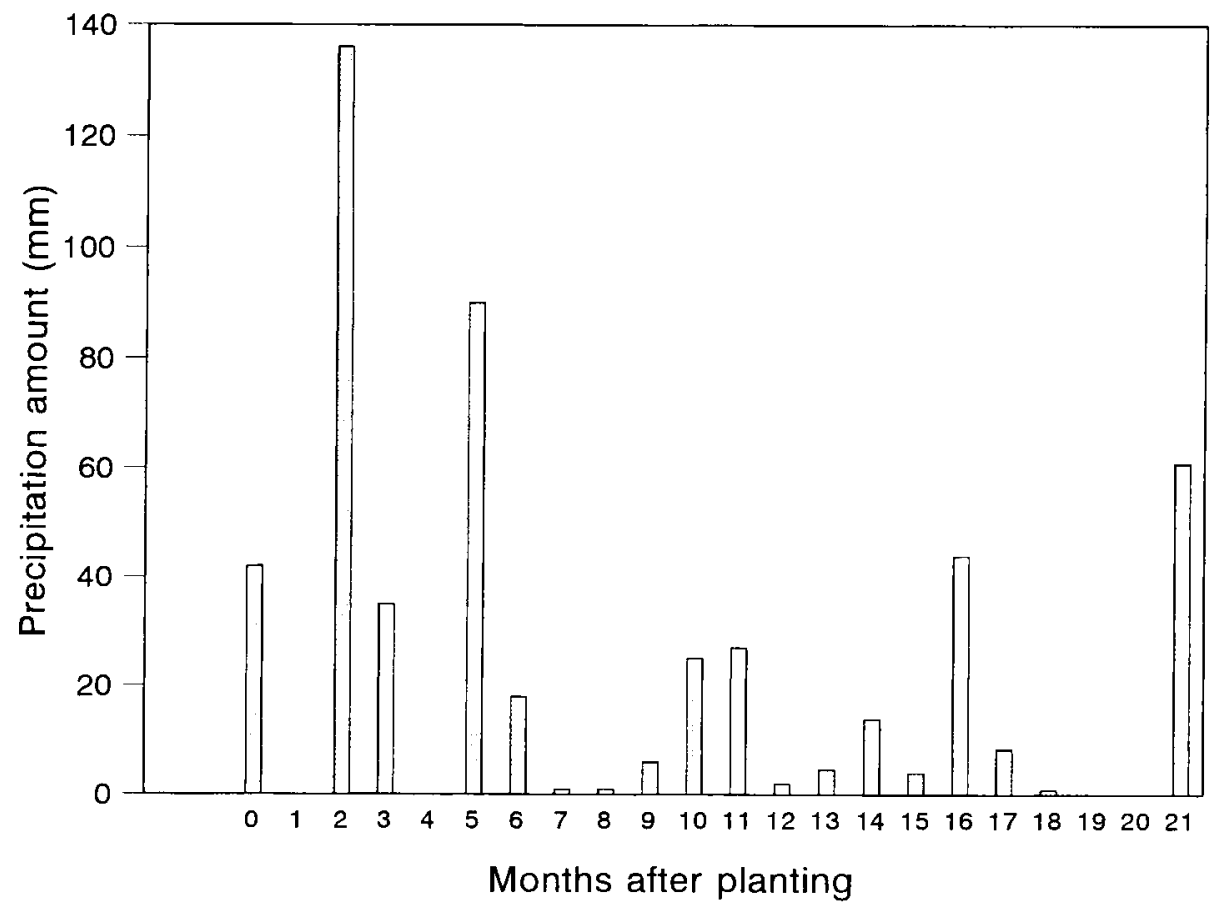

Fig 8. Monthly rainfall amounts recorded during the period of the experiment in the El Aguilucho experimental area. Month $0=$ November 1992.

these properties recovered in the following months.

Finally, the addition of forest soil affected the results in the four treatments. $P$ halepensis growth was significantly enhanced in the mechanical terraces. In the manual terraces without USR, the increase in growth became significant at the end of the period considered, while in the manual terraces with USR a negative effect was observed. Amaranthus and Perry (1987, 1989) studied reafforestation with Douglas fir in the state of Oregon (USA), and they found that soil transferred from wellstocked plantations rapidly stimulates root tip production, more abundant mycorrhiza formation and seedling survival. They also found, however, that the addition of pasteurized soil, presumably free from ectomy- corrhizal propagules, also increased the formation of ectomycorrhizas. The same results were obtained by Colinas et al (1994a, b) who hypothesized that soil transfer provides a rhizosphere environment free from deleterious organisms or volatile organic compounds that stimulate seedling root growth. In our experiment it seems clear that the positive effect of soil addition was not due to an increase in fertility because of the low amount of soil transferred and the high level of fertility produced by the USR.

Further studies are being developed to determine the effect of soil addition on seedling mycorrhization and microbial populations. These may play a major role in plant establishment since the increase in seedling growth observed was mainly 
linked to those treatments which enhanced soil water availability, the principal limiting factor in biological productivity in semi-arid lands.

\section{ACKNOWLEDGMENTS}

This research was supported by Spanish CICYT (FOR-91-0352). We are indebted to F Gutiérrez (ARMAN) for his valuable help during the preparation of the experiment. The authors thank the cooperation of $\mathrm{JL} \mathrm{Al}$ bacete for providing facilities for the installation of the experimental plots.

\section{REFERENCES}

Albaladejo J, Diaz E (1990) Degradación y regeneración del suelo en el litoral mediterráneo español: experiencias en el proyecto LUCDEME. In: Soil Degradation and Rehabilitation in Mediterranean Environmental Conditions (J Albaladejo, MA Stocking, E Diaz, eds), CSIC, Murcia, Spain, 191-214

Albaladejo J, Stocking MA, Diaz E, Castillo V (1994) Land rehabilitation by urban refuse amendments in a semi-arid environment: effect on soil chemical properties. Soil Technol 7, 249-260

Amaranthus MP, Perry DA (1987) Effect of soil transfer on ectomycorrhiza formation and the growth and survival of conifer seedlings on old, nonreforested clearcuts. Can J For Res 17, 944-951

Amaranthus MP, Perry D (1989) Rapid root tip and mycorrhiza formation and increased survival of Douglas-fir seedlings after soil transfer. New For $3,77-82$

Barber RG, Romero D (1994) Effects of bulldozer and chain clearing on soil properties and crop yields. Soil Sci Soc Am J 58, 1768-1775

Barea JM, Azcón R, Hayman DS (1975) Possible synergistic interactions between Endogone and phosphate-solubilizing bacteria in low-phosphate soils. In: Endomycorrhizas (FE Sanders, B Mosse, PB Tinker, eds), Academic Press, London, UK, 409-417

Bastian RK, Ryan JA (1986) Design and management of successful land application system. In: Utilization, Treatment and Disposal of Waste on Land. Soil Sci Soc Am, Madison, WI, USA, 217-234

Biswas TD, Khosla BK (1971) Building up of organic matter status of the soil and its relation to the physical properties. J Soil Sci 19, 31-37

Bortlisz J, Malz F (1983) The influence of the agricultural utilization of domestic sewage sludge on the quality of the soil. In: The Influence of Sewage Sludge Application on Physical and Biological Properties of Soils (C Catraux, P L'Hermite, E Suess, eds), D Reidel, Dordrecht, the Netherlands, 87-106

Brink RH, Dubach P, Lynch DL (1960) Measurements of carbohydrates in soil hydrolizates with anthrone. Soil Sci $89,157-166$
Colinas C, Molina R, Trappe J, Perry D (1994a) Ectomycorrhizas and rhizosphere microorganisms of seedlings of Pseudotsuga menziessi (Mirb) Franco planted on a degraded site and inoculated with forest soils pretreated with selective biocides. New Phytol 127, 529-537

Colinas C, Perry D, Molina R, Amaranthus MP (1994b) Survival and growth of Pseudotsuga menziessi seedlings inoculated with biocide-treated soils at planting in a degraded clearcut. Can J For Res 24, 1741-1749

Colombo B, Baccanti M (1989) A new method for the authomatic and selective determination of total organic carbon in sediments, soils, compost, etc. 11th International Symposium on Microchemical Techniques, Wiesbaden, Germany

Cook RJ, Baker KF (1983) The Nature and Practice of Biological Control of Plant Pathogens. The American Phytopathological Society, Saint Paul, MN, USA

Cumming JR (1993) Growth and nutrition of nonmycorrhizal and mycorrhizal pitch pine (Pinus rigida) seedlings under phosphorus limitation. Tree Physiol 13, 173-187

Dent D, Murtland R (1990) Land evaluation for afforestation in a semi-arid environment: the montane plains of the central highland of North Yemen. $\mathrm{Ca}$ tena 17, 509-523

Diaz E, Roldán A, Lax A, Albaladejo J (1994) Formation of stable aggregates in degraded soil by amendment with urban refuse and peat. Geoderma $63,277-288$

Finkel HJ (1986) Engineering measures for soil and water conservation: terracing and benching. In: Semiarid Soil and Water Conservation (HJ Finkel, ed), CRC Press, FL, USA, 85-91

Forster SM (1980) The role of nitrogen fixation in aggregation and stabilization of dune sand. Proc Soc Gen Microbiol 7, 106

Garcia Abril A, Yoldi L, Canga JL (1989) La repoblación forestal. In: El Libro Rojo de los Bosques Españoles. ADENA NWF, Madrid, Spain, 237-276

Garcia Salmerón J (1990) La repoblación forestal: técnicas y repercusión en la mejora de la calidad del suelo. In: Soil Degradation and Rehabilitation in Mediterranean Environmental Conditions (J Albaladejo, MA Stocking, E Diaz, eds), CSIC, Murcia, Spain, 117-137

Glaub JC, Gouleke GG (1989) Municipal organic wastes and composts for arid areas. Arid Soil Res Rehab 3, 171-184

Gonzalez Alonso S (1989) Guias Metodológicas para la Elaboración de Estudios de Impacto Ambiental. 3 Repoblaciones Forestales. DGMA-MOPU, Madrid, Spain

Gupta SC, Dowdy RH, Larson WE (1977) Hydraulic and thermal properties of a sandy soil as influenced by incorporation of sewage sludge. Soil Sci Soc Am J 41, 601-605

Hall GF, Coker EG (1983) Some effects of sewage sludge on soil physical conditions and plant growth. In: The Influence of Sewage Sludge Application on Physical and Biological Properties of Soils (C Ca- 
traux, P L'Hermite, E Suess, eds), D Reidel, Dordrecht, the Netherlands, 43-60

Keeling AA, Paton IK. Mullet JA (1994) Germination and growth of plants in media containing unstable refuse-derived compost. Soil Biol Biochem 26, 767772

Khaleel R, Redy KR, Overcash MR (1981) Changes in soil properties due to organic waste applications: a review. J Environ Qual 10, 133-141

Lambert DH, Weidensaul TC, Borger DC, Rhodes LH (1985) Use of Sewage Sludge in Forest-tree Seedlings Production. EPA/600/\$2-85/095 US Government Printing Office, Washington, DC, USA

Lynch JM, Bragg E (1985) Microorganisms and soil aggregate stability. Adv Soil Sci 2, 133-171

Marschner H (1986) Mineral Nutrition of Higher Plants. Academic Press, New York, NY, USA

Murphy J, Riley JP (1962) A modified single solution method for the determination of phosphate in natural waters. Anal Chim Acta 27, 31-36

Olsen SR, Cole CV, Watanabe FS, Dean LA (1954) Estimation of available phosphorous in soils by extraction with sodium bicarbonate. US Dep Agric Circ 939, Washington, DC, USA
Page AL, Miller RH, Keeny OR (1982) Methods of Soil Analysis. Part 2. American Society of Agronomy, Madison, WI, USA

Roldán A, Albaladejo J (1993) Vesicular-arbuscular mycorrhiza (VAM) fungal populations in a Xeric Torriorthent receiving urban refuse. Soil Biol Biochem 25 , 451-456

Roldán A, Albaladejo J (1994) Effect of mycorrhizal inoculation and soil restoration on the growth of Pinus halepensis seedlings in a semiarid soil. Biol Fertil Soils 8, 143-149

Roldán A, García-Orenes F, Albaladejo J (1994) An incubation experiment to determine factors involving aggregation changes in an arid soil receiving urban refuse. Soil Biol Biochem 26, 1699-1707

Schollemberger CJ, Simon RH (1954) Determination of exchange capacity and exchangeable bases in soils. Soil Sci 59, 13-24

Serrada R (1990) Consideraciones sobre el impacto de la repoblación forestal en el suelo. Ecologia 1, 453-462

Soil Survey Staff (1975) Soil Taxonomy: ABasic System of Soil Classification for Making and Interpreting Soil Surveys. USDA Handbook 436, US Government Printing Office, Washington, DC, USA

Stocking MA, Albaladejo J (1994) Refuse isn't rubbish. Ambio 23, 229-232 